\title{
Does Cash Flows Useful in Predicting the Company's Financial Health? Empirical Validation by Panel Cointegration Tests
}

\author{
Chaouki Mouelhi ${ }^{1}$
}

\begin{abstract}
The aim of this article is to test the usefulness of cash flows as a measure of companies' financial health. Our approach is different from the previous studies which have animated the debate on the comparison of the explanatory power between accrual and cash-flow. Indeed, we use current developments in cointegration tests on non-stationary dynamic panel data to test the existence of a long-run equilibrium relationship between a ratio based on cash flows (i.e., operating cash flow to total assets ratio) and four financial ratios based on accounting data, namely: working capital to total assets ratio, asset turnover ratio, return on assets ratio, and debt-assets ratio. These four financial ratios are commonly known as relevant indicators regarding the company's financial health regarding its liquidity, operational efficiency profitability, and solvency. Precisely, the panel unit root tests (Im, Pesaran, and Shin (2003)) and the panel cointegration tests (Pedroni (2004)) are applied on a sample of 150 American firms over the period 2010-2017. Our main results led to conclude that the cash flow has an informational content and a significant explanatory power in the prediction of the company's financial health. We provide some explanations for these findings which are supported by a robustness analysis using panel error correction models (PECM).
\end{abstract}

JEL classification numbers: G30, G33, L25, M10.

Keywords: Cash flows, Accruals, Financial health, Explanatory power, Panel cointegration tests.

${ }^{1}$ Department of Management Sciences, University of Quebec at Rimouski.

Article Info: Received: May 8, 2021. Revised: June 5, 2021.

Published online: June 10, 2021. 


\section{Introduction}

The uselessness of cash flows as a measure of the financial health of companies is an animated debate in the financial literature. Despite the multiplicity of empirical studies, this debate is still not closed. This is mainly due to the mixed results of these studies and the absence of powerful theoretical arguments explaining the uselessness or usefulness of cash flows as an indicator of a company's financial performance.

In this study, we have thoroughly reviewed the relevance of the informational content of cash flows by conducting a literature review on the main research studies that have compared the explanatory power of cash flows with that of accounting profits in predicting the financial health of companies. Notably, we have found that the econometric methods used by these studies (i.e., the simple correlation coefficients and the OLS regressions) present a very high risk of spurious regressions. Principally, This is confirmed by the divergent results of these studies, so that it is difficult to verify whether at least part of these results is due to the weakness of the econometric methods used.

It is for this reason that we have re-examined the relevance of cash flows as a measure of the company's financial health by using the dynamic panel data techniques, namely stationarity tests and cointegration tests on panel data. More precisely, we have tested the existence of a long-run equilibrium relationship between a ratio based on cash flows (i.e., operating cash flow to total assets ratio) and four financial ratios commonly known to have an explanatory and predictive power regarding of the financial health of companies.

These are the following ratios:

1. Working capital to total assets ratio as liquidity ratio.

2. Asset turnover ratio (i.e. sales to total assets) as operational efficiency ratio.

3. Return on assets ratio (i.e., net income to total assets) as profitability ratio.

4. Debt-assets ratio (i.e., total debts to total assets) as solvency ratio.

The panel stationarity tests of Im, Pesaran, and Shin (2003) and the panel cointegration tests of Pedroni (2004) have been carried out on a homogeneous sample (i.e., according to size company and its life cycle) consists of 150 American companies over the period 2010-2017. The panel data of our study have been extracted from the Compustat database.

The remainder of this paper proceeds as follows. Section 2 presents a literature review about the main studies carried out on the informational content of cash flows. Section 3 describes our research methodology, the sample, the study period, and the research hypotheses. In section 4 , the results of panel stationarity tests and panel cointegration tests are reported and commented. The results of the robustness analysis are presented in section 5. Finally, section 6 provides a conclusion. 


\section{Literature Review}

In this section, we present the main research studies that have animated the debate on the usefulness of the informational content of cash flows. For the purposes of brevity and clarity, we classify these studies into three categories:

1. The studies that have compared the predictive power of cash flow to that of accounting profits in future performance of companies.

2. The studies that examined time trends in the relevance of these predictive powers.

3. The studies that tested the relationship between the company's financial health and indicators based on accounting data and those based on cash flows.

Most of the studies which belong to the first category has explored the ability of current cash flows and current accounting profits to predict future operating cash flows of companies. The results of these studies have been controversial and inconclusive. Indeed, several studies have shown the supremacy of the predictive power of accounting profits compared to that of cash flows. Particularly, we cite the following research studies: Brooks (1981), Greenberg, Johnson, and Ramesh (1986), Murdoch and Krause (1989), Lorek and Willinger (1996), Dechow, Khotari, and Watts (1998), Pae (2005), Kim and Kross (2005), Ebaid (2011), and Nam, Brochet, and Ronen (2012).

Conversely, a significant number of studies have shown that cash flows have a higher capacity than accounting profits in predicting future operating cash flows of companies. Among these studies, we principally mention Bowen, Burgstahler, and Daley (1986), Finger (1994), Burgstahler, Jiambalvo, and Pyo (1998), Chotkunakitti (2005), Seng (2006), Subramanyam and Venkatachalam (2007), Arthur, Czernkowski, and Chen, (2007), Lorek and Willinger (2009), Penham and Yehuda, (2009), Waldron and Jordan (2010), and Chen, Melessa, and Mergenthaler (2017). The mixed results of this first category can be explained mainly by two factors, namely the variety of the approaches applied to measure cash flows, and the diversity in the econometric methods used.

In addition, it should be noted that several studies have found that the supremacy of accounting profits in predicting future operating cash flows of companies is attributable to accrued liabilities. Therefore, any systematic change in the properties of accrued liabilities could reduce the predictive power of accounting profits in favor of that of cash flows. For example, Dechow (1994) has shown that cash flows and accrued liabilities are negatively correlated. However, Bushman, Lerman, and Zhang (2016) have found that this negative correlation has diminished over time and has even turned positive in recent years.

The systematic changes in the properties of accrued liabilities lead us to the studies of the second category, namely those which have examined the temporal trends in the predictive power of accounting profits and that of cash flows. Among these studies, we particularly mention Kim and Kross (2005) who have shown that the predictive power of accounting profits increases over time. Conversely, Lorek and Willinger (2009) have found that accounting profits and cash flows do not display 
time trends in their respective power to predict future operating cash flows of companies.

Regarding the studies of the third category, we briefly present the main studies that have investigated the uselessness of cash flows as an indicator of the company's financial health. Several studies have provided strong empirical support on the relevance of cash flows in predicting corporate financial distress. For example, Beaver (1966) has used a dichotomous classification test via the univariate analysis to show that the ratio of operating cash flow to total debt has the highest discriminating power over a five-year period. However, the results of Beaver (1966) have been strongly criticized by several researchers because the univariate analysis does not consider the interaction between the variables. For a such reason, many studies have used the discriminant analysis to overcome the limitations of the univariate analysis. Altman (1968) has used the cash flow to fixed charge ratio with four other ratios in his multiple discriminant analysis to identify the linear combination of ratios that best discriminates between bankrupt and healthy companies. He has shown the relevance of the cash flow to fixed charges ratio as well as its discriminating model (97.7\% classification accuracy 1 and 2 years before bankruptcy). Deakin (1972) has applied a discriminant analysis like that of Altman (1968) by using all ratios of Beaver (1966) to predict company bankruptcy. The results of Deakin (1972) have confirmed the relevance predictive power of operating cash flows to total debt ratio even 3 years before bankruptcy. Likewise, Blum (1974) has shown that cash flows present a significant informational content to predict the company bankruptcy.

Holmen (1988) has compared the model of Beaver (1966) and that of Altman (1968). Thereafter, He has found that the univariate use of operating cash flows to total debts ratio as proposed by Beaver (1966), allowed to predict failure with a bit error rate less than that of the five ratios of the Z score of Altman (1968). Casey and Bartczak (1984) have studied 290 American companies, including 60 companies which have declared bankruptcy between 1971 and 1982. The results of Casey and Bartczak (1984) showed that the informational content of the cash flows of companies over a five-year period was completely useless in distinguishing between those that were healthy and those that were going to bankruptcy. Specifically, Casey and Bartczak (1984) have found that operating cash flow data over the five years prior to companies' bankruptcy are poor indicators and produce forecasts that are lower than the combination of the six conventional ratios. However, Saint-Pierre (1985) has strongly criticized the results of Casey and Bartczak (1984) by advancing the following arguments:

1. Casey and Bartczak have favored the six conventional ratios at the expense of cash flows. So that it is totally incorrect to compare the results of a multidimensional analysis (i.e., the six conventional ratios) to those of a onedimensional analysis (i.e., cash flows). 
2. Casey and Bartczak have made no further assumptions on the probability laws of the quantifying characters concerning the a priori probability that a company belongs to the group of bankrupt companies or to the group of non-bankrupt companies.

According to Saint-Pierre (1985), it is not appropriate to infer generalities from the results of Casey and Bartczak (1984).

Finally, among the main studies which have confirmed the usefulness of cash flows as a relevant indicator of a company's financial distress, we mainly reference Norton and Smith (1979), Largay and Stickney (1980), and Takahashi, Kurokawa and Watase (1984).

\section{Research Methodology}

\subsection{Choice of variables}

Our research methodology consists of testing the existence of cointegration relationships between a ratio based on cash flows and four financial ratios based on accounting data in order to examine the relevance of cash flows as an indicator of the companies' financial health. More precisely, we have chosen four conventional financial ratios which are commonly known in the literature as being relevant indicators regarding the financial health of a company through the following aspects: liquidity, operational efficiency, profitability, and solvency. Table 1 below shows the selected ratios.

Table 1: The selected financial ratios

\begin{tabular}{|c|c|}
\hline Ratio based on cash flows & Financial ratios based on accounting data \\
\hline $\begin{array}{l}C F R=\text { operating cash flows to total } \\
\text { assets ratio }\end{array}$ & $\begin{array}{l}\text { Liquidity ratio: } \\
L I Q R=\text { working capital to total assets ratio. } \\
\text { Operational efficiency ratio: } \\
E F F R \text { : sales to total assets ratio } \\
\text { (i.e., asset turnover ratio) } \\
\text { Profitability ratio: } \\
P R O R=\text { net income to total assets ratio } \\
\text { (i.e., return on assets ratio) } \\
\text { Solvency ratio: } \\
S O L R=\text { total debts to total assets ratio } \\
\text { (i.e., debt-assets ratio) }\end{array}$ \\
\hline
\end{tabular}

There are two reasons which justify the choice of these ratios, at first, their extensive use in practice for the companies' financial diagnosis, and secondly these ratios have been the subject of numerous empirical studies which have analyzed the relevance of their informational content regarding the companies' financial health. 


\subsection{Research hypotheses}

We recall that our aim in this study is to test the existence of a long-run equilibrium relationship (i.e., cointegration relationship) between the operating cash flows to total assets ratio (i.e., CFR) and the four conventional financial ratios which are based on accounting data. The existence of a cointegration relationship between CFR and one of these four conventional financial ratios informs us about the usefulness of the informational content of cash flows in measuring and predicting one of particular aspects of a companies' financial health, namely liquidity, operational efficiency, profitability, and solvency. Thus, we test the following four research hypotheses:

Hypothesis 1 (H1): operating cash flow to total assets ratio (CFR) and working capital to total assets ratio (LIQR) are cointegrated.

The empirical validation of Hypothesis 1 means that the informational content of cash flows has a relevant explanatory power regarding companies' liquidity.

Hypothesis 2 (H2): operating cash flow to total assets ratio (CFR) and sales to total assets ratio (EFFR) are cointegrated.

The empirical validation of Hypothesis 2 means that the informational content of cash flows has a relevant explanatory power regarding companies' operational efficiency.

Hypothesis 3 (H3): operating cash flow to total assets ratio (CFR) and net income to total assets ratio (PROR) are cointegrated.

The empirical validation of Hypothesis 3 means that the informational content of cash flows has a relevant explanatory power regarding companies' profitability.

Hypothesis 4 (H4): operating cash flow to total assets ratio (CFR) and total debts to total assets ratio (SOLR) are cointegrated.

The empirical validation of Hypothesis 4 means that the informational content of cash flows has a relevant explanatory power regarding companies' solvency.

\subsection{Study data: Sample and period}

The stationarity and cointegration tests on panel data require a minimum of homogeneity to reach robust results. It is for this reason that we have taken this particularity into account when constructing our study sample which is composed of 150 American companies. More specifically, we have opted for a sample that is homogeneous in terms of the size and the life cycle of the company. Indeed, several studies have found that the explanatory power of financial indicators varies depending on the size of the company. The results of these studies have shown the irrelevance of the explanatory and predictive power of some financial indicators regarding the performance of large companies. This is explained by the fact that the financial market already has a lot of information about these companies even before 
the disclosure of their financial indicators. Contrariwise, in the case of small companies, these same financial indicators have relevant informational content to explain and predict their financial health. Therefore, in this article we are only interested in small companies and so the sample will be homogeneous in terms of company size.

Regarding the life cycle, we know that companies have their own life cycle and go through the following four phases: start-up, growth, maturity, and decline. Each of the four phases has different characteristics in terms of funding needs, stability of equity, risk, and results. In the maturity phase, companies have made most of their profitable investments. As a result, their growth opportunities are relatively low as well as their risk. In addition, during the maturity phase, the equity and their costs are more stable, and companies can distribute a significant portion of their profits (i.e., dividends) to their shareholders. Thus, as companies grow and reach maturity, their accounting results and risk exposure follow trends that are not difficult to predict by investors on financial markets.

However, in the start-up or growth phases, the activity of the company is in full expansion, the growth opportunities are important and the risk and the capital which are used to finance the investment projects are relatively higher and unstable. As a result, the accounting results and risk exposure of companies during these two phases are difficult to predict. For this reason, in this study, we are only interested in companies that are in their maturity phase and so the sample will also be homogeneous in terms of company's life cycle.

As a result, we have built a homogeneous sample which includes small companies which are in their phase of maturity. More specifically, the study sample was formed according to the following five steps:

Step 1: We have set study period over 8 years, namely from 2010 to 2017 with annual-frequency data.

Step 2: From the Compustat database, we have selected all American companies that have total assets lower than the median of the average total assets over the entire period. Thereafter, we have considered these companies as were small.

Step 3: We have selected all companies that have been in business for 15 years in 2010. Afterwards, we have considered these companies as were in their maturity phase.

Step 4: We have excluded all financial services companies (SIC code 6000-6999).

Step 5: Among all the companies that met our selection criteria (i.e., steps 1 to 4), we have randomly selected 150 companies.

By following these steps, we have obtained a homogeneous sample (i.e., in terms of size and life cycle) of 150 American companies over the period 2010 - 2017, which gave us 1200 observations in panel data (company-year). 
Table 2 classifies the companies of our final sample by industry sector based on the 2-Digit SIC code.

Table 2: Classification of the companies according to 2- Digit SIC Code

\begin{tabular}{|c|c|c|c|}
\hline $\begin{array}{c}\text { 2-Digit SIC } \\
\text { Code }\end{array}$ & Industry sector & $\begin{array}{c}\text { Number of } \\
\text { companies }\end{array}$ & $\begin{array}{c}\text { Percentage } \\
(\%)\end{array}$ \\
\hline $10-14$ & Mining & 7 & $4,67 \%$ \\
\hline $15-17$ & Construction & 16 & $10,67 \%$ \\
\hline $20-39$ & Manufacturing & 59 & $39,33 \%$ \\
\hline $40-49$ & Transport and Public Utilities & 26 & $17,33 \%$ \\
\hline $50-51$ & Wholesale Trade & 15 & $10 \%$ \\
\hline $52-59$ & Retail Trade & 11 & $7,33 \%$ \\
\hline $70-89$ & Services & 16 & $10,67 \%$ \\
\hline Total & & 150 & $100 \%$ \\
\hline
\end{tabular}

\subsection{Panel stationarity and cointegration tests}

We have used current econometrics developments in non-stationary dynamic panel to test our four research hypotheses. First, for panel stationarity tests, we have used the unit root test of Im, Pesaran and Shin (2003) which allows, under the alternative hypothesis, the heterogeneity of the autoregressive root as well as the heterogeneity regarding the presence of a unit root in the panel. As we know, the unit root test of $\mathrm{Im}$, Pesaran and Shin (2003) is based on two simple statistics calculated by the average of the individual statistics of the "Dickey-Fuller" (DF) or "Dickey-Fuller Augmented" (ADF). In addition, the robustness of the ADF (K) tests is very sensitive to the number of number of delays K. For this reason, we have been careful in the choice of the optimal number of delays $\mathrm{K}^{*}$ by using three criteria: the Akaike information criterion (AIK), the Schwartz criterion (SC) and the Hannan-Quinn criterion (HQC).

Subsequently, for the panel cointegration test, we have used the tests of Pedroni (2004) which have several advantages over other cointegration tests on panel data that exist in the literature. Indeed, the tests of Pedroni (2004), as the stationarity test of Im, Pesaran and Shin (2003), consider the heterogeneity of individuals (i.e., companies) through the specific parameters for each individual (i.e., company) of the sample. This heterogeneity can be found at the level of long-run equilibrium relationships (i.e., cointegration relationships) as well as at the level of short-run dynamics. This means that, in the alternative hypothesis, there is a cointegrating relation for each individual (i.e., company) with the possibility that this cointegration relationship may differ from an individual (i.e., company) to the other. Finally, We note that the permission of such heterogeneity constitutes an undeniable advantage since in practice, it is unusual for the cointegrating vector to be identical for all the individuals (i.e., companies) of the panel.

Pedroni (2004) has proposed seven statistics to test the null hypothesis of no cointegration. Four of these statistics are based on the within-dimension called panel 
cointegration statistics, namely panel V-statistic, panel Rho-statistic, panel PPstatistic and panel ADF-statistic. The other three statistics are based on the betweendimension called group-mean panel cointegration statistics, namely group Rhostatistic, group PP-statistic, and group ADF-statistic. It should be noted that the seven statistics of Pedroni (2004) are carried out on a specification with constant and deterministic trend. Furthermore, the tests of Pedroni (2004), as the test of Im, Pesaran and Shin (2003), admit the hypothesis of independence between individuals (i.e., companies) since they belong to the first generation of tests on panel data.

The models to be tested which correspond to our four research hypotheses are as follows:

Model 1: $\mathrm{CFR}_{\mathrm{i}, \mathrm{t}}=\alpha_{\mathrm{i}}+\delta_{\mathrm{i}} \mathrm{t}+\beta_{\mathrm{i}, \mathrm{t}} \mathrm{LIQR}_{\mathrm{i}, \mathrm{t}}+\varepsilon_{\mathrm{i}, \mathrm{t}}$

Model 2: $\mathrm{CFR}_{\mathrm{i}, \mathrm{t}}=\alpha_{\mathrm{i}}+\delta_{\mathrm{i}} \mathrm{t}+\beta_{\mathrm{i}, \mathrm{t}} \mathrm{EFFR}_{\mathrm{i}, \mathrm{t}}+\varepsilon_{\mathrm{i}, \mathrm{t}}$

Model 3: $\mathrm{CFR}_{\mathrm{i}, \mathrm{t}}=\alpha_{\mathrm{i}}+\delta_{\mathrm{i}} \mathrm{t}+\beta_{\mathrm{i}, \mathrm{t}} \mathrm{PROR}_{\mathrm{i}, \mathrm{t}}+\varepsilon_{\mathrm{i}, \mathrm{t}}$

Model 4: $\mathrm{CFR}_{\mathrm{i}, \mathrm{t}}=\alpha_{\mathrm{i}}+\delta_{\mathrm{i}} \mathrm{t}+\beta_{\mathrm{i}, \mathrm{t}} \operatorname{SOLR}_{\mathrm{i}, \mathrm{t}}+\varepsilon_{\mathrm{i}, \mathrm{t}}$

with,

- $\mathrm{CFR}_{\mathrm{i}, \mathrm{t}}$ : operating cash flows to total assets ratio of company $\mathrm{i}$ for year $\mathrm{t}$.

- $\mathrm{LIQR}_{\mathrm{i}, \mathrm{t}}$ : working capital to total assets ratio of company $\mathrm{i}$ for year $\mathrm{t}$.

- EFFR $_{i, t}$ : sales to total assets ratio of company $i$ for year $t$.

- PROR $_{i, t}$ : net income to total assets ratio of company $i$ for year $t$.

- SOLR $\mathrm{i}_{\mathrm{t}, \mathrm{t}}$ : total debts to total assets ratio of company $\mathrm{i}$ for year $\mathrm{t}$.

$\mathrm{i}=1,2 \ldots, \mathrm{N}$ denotes companies and $\mathrm{t}=1,2 \ldots, \mathrm{T}$ denotes year.

\section{Results and Interpretations}

\subsection{Results of panel stationarity tests}

Table 3 presents the results of the $\operatorname{ADF}(K)$ tests of $\mathrm{Im}$, Pesaran and Shin (2003) on the series at the level of the five variables, namely the ratio based on cash flow (CFR) and the four financial ratios based on accounting data (LIQR, EFFR, PROR and SOLR). We recall that these $\operatorname{ADF}(\mathrm{K})$ tests were carried out on a specification with constant, and deterministic trend. In addition, all statistics for these tests are in standardized form and follow the normal distribution. The $\operatorname{ADF}(K)$ statistics for the three information criteria (AIK, SC and HQC) show the non-rejection of the null hypothesis (i.e., non-stationarity) for the five studied variables (i.e., CFR, LIQR, EFFR, PROR, and SOLR). Thus, these results allow us to conclude that all variables have satisfied the first condition necessary for the application of the panel cointegration tests, namely that the series at the level must be non-stationary (i.e., not integrated of order 0 ). 
Table 3: Panel stationarity tests on levels

\begin{tabular}{|c|c|c|c|}
\hline Variables & $\begin{array}{c}\text { Statistics ADF(K*) } \\
\text { According to AIK }\end{array}$ & $\begin{array}{l}\text { Statistics ADF(K*) } \\
\text { According to SC }\end{array}$ & $\begin{array}{c}\text { Statistics ADF(K*) } \\
\text { According to HQC }\end{array}$ \\
\hline CFR & 4.54236 & 4.62331 & 4.69985 \\
& $(1.000)$ & $(1.000)$ & $(1.000)$ \\
\hline LIQR & 4.09522 & 4.18245 & 3.85366 \\
& $(1.000)$ & $(1.000)$ & $(0.999)$ \\
\hline EFFR & 5.22963 & 4.90284 & 5.55298 \\
& $(1.000)$ & $(1.000)$ & $(1.000)$ \\
\hline PROR & 3.09228 & 3.29854 & 3.78281 \\
& $(0.997)$ & $(0.998)$ & $(0.999)$ \\
\hline SOLR & 4.29366 & 3.95887 & -4.48196 \\
& $(1.000)$ & $(0.999)$ & $(1.000)$ \\
\hline
\end{tabular}

CFR: operating cash flows to total assets ratio, LIQR: working capital to total assets ratio, EFFR: sales to total assets ratio, PROR: net income to total assets ratio, and SOLR: total debts to total assets ratio. $\mathrm{K}^{*}$ by AIK corresponding to the minimum lag order under Akaike Information Criterion, $\mathrm{K}^{*}$ by SC corresponding to the minimum lag order under Schwarz Criterion and $\mathrm{K}^{*}$ by HQC corresponding to the minimum lag order under Hann-Quinn Criterion. The null hypothesis is that variable contains a unit root (i.e., non-stationarity). The alternative hypothesis is that the variables are stationary. $(* * *),(* *),(*)$ statistically significant at $1 \%, 5 \%$, and $10 \%$, respectively. Numbers in parentheses represent $\mathrm{p}$-value. $\mathrm{N}=150$ and $\mathrm{T}=8$.

The results of the $\mathrm{ADF}(\mathrm{K})$ tests of Im, Pesaran and Shin (2003) on the series at the first differences of the five variables (i.e., CFR, LIQR, EFFR, PROR, and SOLR) are presented in Table 4. The $\operatorname{ADF}(\mathrm{K})$ statistics for the three information criteria (AIK, SC and HQC) reject the null hypothesis of non-stationarity at the $1 \%$ significance level, and this for the five studied variables. This means that our five variables are integrated of order 1 and therefore they have satisfied the second condition necessary for the application of the panel cointegration tests, namely that the first differences of the series must be stationary (i.e., integrated of order 1: $\mathrm{CFR} \sim \mathrm{I}(1), \mathrm{LIQR} \sim \mathrm{I}(1), \quad \mathrm{EFFR} \sim \mathrm{I}(1), \mathrm{PROR} \sim \mathrm{I}(1)$, and SOLR I(1)). 
Table 4: Panel stationarity tests on first differences

\begin{tabular}{|c|c|c|c|}
\hline Variables & $\begin{array}{l}\text { Statistics ADF }\left(K^{*}\right) \\
\text { According to AIK }\end{array}$ & $\begin{array}{c}\text { Statistics ADF }\left(\mathrm{K}^{*}\right) \\
\text { According to } \mathrm{SC}\end{array}$ & $\begin{array}{l}\text { Statistics ADF }\left(K^{*}\right) \\
\text { According to } \mathrm{HQC}\end{array}$ \\
\hline CFR & $\begin{array}{c}-15.2156 * * * \\
(0.000)\end{array}$ & $\begin{array}{c}-15.5523 * * * \\
(0.000)\end{array}$ & $\begin{array}{c}-15.2156^{* * * *} \\
(0.000)\end{array}$ \\
\hline LIQR & $\begin{array}{c}-17.0952 * * * \\
(0.000)\end{array}$ & $\begin{array}{c}-17.2526 * * * \\
(0.000)\end{array}$ & $\begin{array}{c}-17.1667 * * * \\
(0.000)\end{array}$ \\
\hline EFFR & $\begin{array}{c}-24.6744 * * * \\
(0.000)\end{array}$ & $\begin{array}{c}-25.0058 * * * \\
(0.000)\end{array}$ & $\begin{array}{c}-25.8432 * * * \\
(0.000)\end{array}$ \\
\hline PROR & $\begin{array}{c}-21.6684 * * * \\
(0.000)\end{array}$ & $\begin{array}{c}-21.9522 * * * \\
(0.000)\end{array}$ & $\begin{array}{c}-21.7720 * * * \\
(0.000)\end{array}$ \\
\hline SOLR & $\begin{array}{c}-18.8532 * * * \\
(0.000)\end{array}$ & $\begin{array}{c}-19.1741 * * * \\
(0.000)\end{array}$ & $\begin{array}{c}-19.0362 * * * \\
(0.000)\end{array}$ \\
\hline
\end{tabular}

CFR: operating cash flows to total assets ratio, LIQR: working capital to total assets ratio, EFFR: sales to total assets ratio, PROR: net income to total assets ratio, and SOLR: total debts to total assets ratio. $\mathrm{K}^{*}$ by AIK corresponding to the minimum lag order under Akaike Information Criterion, $\mathrm{K}^{*}$ by SC corresponding to the minimum lag order under Schwarz Criterion and $\mathrm{K}^{*}$ by HQC corresponding to the minimum lag order under Hann-Quinn Criterion. The null hypothesis is that variable contains a unit root (i.e., non-stationarity). The alternative hypothesis is that the variables are stationary. $(* * *),(* *),(*)$ statistically significant at $1 \%, 5 \%$, and $10 \%$, respectively. Numbers in parentheses represent p-value. $\mathrm{N}=150$ and $\mathrm{T}=8$.

In conclusion, the results of the panel stationarity test of Im, Pesaran and Shin (2003) allow us to apply the panel cointegration tests of Pedroni (2004) on the following four models:

Model 1 is used to test the existence of a cointegration relationship between CFR and LIQR.

Model 2 is used to test the existence of a cointegration relationship between CFR and EFFR.

Model 3 is used to test the existence of a cointegration relationship between CFR and PROR.

Model 4 is used to test the existence of a cointegration relationship between CFR and SOLR.

\subsection{Results of panel cointegration tests}

As mentioned above, the panel cointegration test of Pedroni (2004) consists of taking the no cointegration as the null hypothesis and using seven different statistics to test the existence of cointegration relationship between two variables on panel data, namely four statistics based on the within-dimension and three statistics based on the between-dimension. Statistically, the rejection of the null hypothesis by the test of Pedroni (2004) means that a sufficient number of companies in the study sample gives statistics far from the predictions of the theory that their values would be generated under the null hypothesis of no cointegration. In other words, the rejection of the null hypothesis means that a sufficient number of companies in the sample have statistics values which indicate the existence of a statistically and 
significantly long-run dynamic equilibrium relationship (i.e., cointegration relationship) between the two studied variables. Thus, in this study, for each tested model, the rejection of the null hypothesis indicates the existence of a cointegration relationship between CFR and one of the four ratios which are based on the accounting data, namely LIQR, EFFR, PROR, and SOLR.

The particularity of the panel cointegration test of Pedroni (2004) lies in the fact that its seven statistics do not always lead to the same results concerning the rejection or non-rejection of the null hypothesis of no cointegration. For this reason, we have ranked these seven statistics tests in terms of their robustness considering the specific characteristics of our sample regarding its size and the study period.

First, from the various simulations carried out, Pedroni (1997) has showed that the seven statistics are relevant insofar as they do not suffer from threshold distortion. However, according to Pedroni (2000), the statistics of the between-dimension category have several advantages over the statistics of the within-dimension category since they assume heterogeneity of the transient dynamics between individuals (i.e., companies). In addition, Pedroni (2000) has showed that for small samples $(\mathrm{T} \leq 20)$, the statistics of the between-dimension category have significantly less distortions than the statistics of the within-dimension category. Given the relatively heterogeneous nature of our sample (i.e., the sample is homogeneous in terms only of two factors, namely the size and the life cycle, but it remains heterogeneous with regard to several other factors) as well as the number of observations for each company which is relatively small $(\mathrm{T}=8)$, we have considered that the three statistics of the between-dimension category (i.e., group Rho-statistic, group PP-statistic, and group ADF-statistic) are more robust to test the null hypothesis of no cointegration in the present study.

Therefore, we have first used the result of the three statistics of the betweendimension category to compare the statistical intensity of possible cointegration relationships between the ratio based on cash flows (CFR) and one of the four ratios based on accounting data (LIQR, EFFR, PROR, and SOLR). Second, we have used the result of the four statistics of the within-dimension category. Specifically, it is the number of the statistics of the between-dimension category that reject the null hypothesis of no cointegration, which will inform us about the powerfulness of each identified cointegration relationship. For example, if the three statistics of the the between-dimension category reject the null hypothesis of no cointegration in a first model, then only two out of three statistics in the same category reject the null hypothesis of no cointegration in a second model. In such a case, we can conclude that the cointegration relationship identified between the two variables of the first model is more powerful than that identified between the two variables of the second model. In the case where the number of statistics of the between-dimension category which rejected the null hypothesis of no cointegration is the same for both models, then we use the number of statistics of the within-dimension category, which reject null hypothesis of no cointegration, to identify which model shows the most powerful cointegration relationship. 
Table 5 presents the results of panel cointegration tests of Pedroni (2004) between the ratio based on cash flows (CFR) and the four ratios based on accounting data (LIQR, EFFR, PROR, and SOLR).

First, we note that for model 1 (CFR-LIQR), there are five statistics which reject the null hypothesis of no cointegration at the $1 \%$ significance level, namely two statistics of the between-dimension category (i.e., group PP-statistic and group ADF-statistic) and three statistics of the within-dimension category (i.e., panel Rhostatistic, panel PP-statistic, and panel ADF- statistic). However, the group Rhostatistic of the between-dimension category and the panel v-statistic of the withindimension category do not reject the null hypothesis of no cointegration. Overall, these results allow us to conclude the existence of a cointegration relationship between CFR and LIQR, and so the hypothesis 1 is accepted. Subsequently, for model 2 (CFR -EFFR), the results show that all the statistics except the group Rhostatistic of the between-dimension category reject the null hypothesis of no cointegration at a significance level of $1 \%$ and $5 \%$. Thus, we can conclude that $\mathrm{CRF}$ and EFFR are cointegrated. In other words, these results support the validation of Hypothesis 2. Then, for model 3 (CFR-PROR), we notice that the three statistics of the between-dimension category reject the null hypothesis of no cointegration at a significance level of $1 \%$. For the within-dimension category, the panel v-statistic test rejects the null hypothesis at a significance level of $10 \%$, and the other three statistics (i.e., panel Rho-statistic, panel PP-statistic, and panel ADF-statistic) reject it at a significance level of $1 \%$. These results indicate the existence of a cointegration relationship between CFR and PROR. Thus, we conclude that hypothesis 3 is also accepted. Finally, with regard to model 4 (CFR-SOLR), the results show that CFR and SOLR are cointegrated since the three statistics of the between-dimension category as well as the four statistics of the within-dimension category reject the null hypothesis of no cointegration at a significance level of $1 \%$. Thus, the results allow us to accept hypothesis 4 . 
Table 5: Panel cointegration tests

\begin{tabular}{|l|c|c|c|c|}
\hline \multicolumn{1}{|c|}{ Statistics tests } & $\begin{array}{c}\text { Model 1 } \\
\text { CFR-LIQR }\end{array}$ & $\begin{array}{c}\text { Model 2 } \\
\text { CFR-EFFR }\end{array}$ & $\begin{array}{c}\text { Model 3 } \\
\text { CFR-PROR }\end{array}$ & $\begin{array}{c}\text { Model 4 } \\
\text { CFR-SOLR }\end{array}$ \\
\hline \multicolumn{5}{|c|}{ Group statistics (between-dimension) } \\
\hline Group Rho-statistic & 1.30873 & 1.17743 & $3.79332^{* * *}$ & $3.35180^{* * * *}$ \\
& $(0.256)$ & $(0.208)$ & $(0.000)$ & $(0.000)$ \\
\hline Group PP-statistic & $-9.86613^{* * *}$ & $-14.2156^{* * *}$ & $-22.7761^{* * *}$ & $-31.8634^{* * *}$ \\
& $(0.000)$ & $(0.000)$ & $(0.000)$ & $(0.000)$ \\
\hline Group ADF-statistic & $-20.8287^{* * *}$ & $-11.3486^{* * *}$ & $-25.4553^{* * *}$ & $-23.5862^{* * *}$ \\
& $(0.000)$ & $(0.000)$ & $(0.000)$ & $(0.000)$ \\
\hline \multicolumn{5}{|c|}{ Panel statistics (within-dimension) } \\
\hline Panel v-statistic & 1.73752 & $2.04556^{* *}$ & $2.33673^{*}$ & $5.65733^{* * * *}$ \\
& $(0.187)$ & $(0.048)$ & $(0.076)$ & $(0.000)$ \\
\hline Panel Rho -statistic & $-6.38876^{* * *}$ & $-9.44711^{* * *}$ & $-19.2256^{* * *}$ & $-26.4778^{* * *}$ \\
& $(0.000)$ & $(0.000)$ & $(0.000)$ & $(0.000)$ \\
\hline Panel PP-statistic & $-17.3447 * * *$ & $-19.0877^{* * *}$ & $-26.3952^{* * *}$ & $-35.6521 * * *$ \\
& $(0.000)$ & $(0.000)$ & $(0.000)$ & $(0.000)$ \\
\hline Panel ADF-statistic & $-23.3889^{* * *}$ & $-15.7621^{* * *}$ & $-26.9343^{* * *}$ & $-30.4467 * * *$ \\
& $(0.000)$ & $(0.000)$ & $(0.000)$ & $(0.000)$ \\
\hline
\end{tabular}

CFR: operating cash flows to total assets ratio, LIQR: working capital to total assets ratio, EFFR: sales to total assets ratio, PROR: net income to total assets ratio, and SOLR: total debts to total assets ratio. The null hypothesis is no cointegration. The alternative hypothesis is that the two variables are cointegrated. $(* * *),(* *)$, (*) statistically significant at $1 \%, 5 \%$, and $10 \%$, respectively. Numbers in parentheses represent p-value. $\mathrm{N}=$ 150 and $\mathrm{T}=8$.

Regarding the powerfulness of the cointegration relationships among the four tested models, we can deduct from the results of the group statistics (i.e., statistics of the between-dimension category) that the cointegration relationships for the models (CFR-PROR) and (CFR-SOLR) are more powerful than those for the models (CFRLIQR) and (CFR-EFFR). Indeed, for the models (CFR-PROR) and (CFR-SOLR), the three statistics of the between-dimension category (i.e., group Rho-statistic, group PP-statistic, and group ADF-statistic) reject the null hypothesis of no cointegration at a $1 \%$ significance level. While for the models (CFR-LIQR) and (CFR-EFFR), only two statistics of the between-dimension category (i.e., group PPstatistic and group ADF-statistic) reject the null hypothesis of no cointegration at a $1 \%$ significance level. Thereafter, looking at the results of the statistics of the within-dimension category, we can infer that the cointegration relationship between CFR and SOLR (model 4) is slightly more powerful than that between CFR and PROR (model 3). In fact, for the model (CFR-SOLR), the four panel-statistics (i.e., statistics of the within-dimension category, namely panel v-statistic panel Rhostatistic, panel PP-statistic, and panel ADF-statistic) reject the null hypothesis of no cointegration at a significance level of $1 \%$. Nevertheless, for the model (CFRPROR), we notice that only three statistics of the within-dimension category (i.e., panel Rho-statistic, panel PP-statistic, and panel ADF-statistic) reject the null 
hypothesis of no cointegration at a $1 \%$ significance level.

We recall that for the both models (CFR-LIQR) and (CFR-EFFR), we have found that two statistics of the between-dimension category reject the null hypothesis of no cointegration at a significance level of $1 \%$. This means, that we use the same line of reasoning based on the number of panel-statistics (i.e., statistics of the withindimension category), to compare the powerfulness of the cointegration relationships between these two models. For this, we notice that for the model (CFR-EFFR), the four statistics of the within-dimension category (i.e., panel v-statistic, panel Rhostatistic, panel PP-statistic, and panel ADF-statistic) reject the null hypothesis of no cointegration at a significance level of $1 \%$ and 5\%. However, for the model (CFRLIQR) only three statistics of the within-dimension category (i.e., panel Rhostatistic, panel PP-statistic, and panel ADF-statistic) reject the null hypothesis of no cointegration at a $1 \%$ significance level. Thus, we conclude from these results that the cointegration relationship between CFR and EFFR (model 2) is more powerful than that between CFR and LIQR (model 1).

As a conclusion, our ranking according to the powerfulness of the cointegration relationships among the four tested models is as follows: in the first position, we find the model (CFR-SOLR) which displays the most powerful cointegration relationship. Then, the model (CFR-PROR) which is positioned in the second position. Next, we have the model (CFR-EFFR) in the third position. Finally, the model (RCF - LIQR) occupies the fourth and last position since it displays the weakest cointegration relationship among the four tested models.

\section{Robustness analysis}

The robustness analysis consists of the use of the dynamic panel econometrics techniques to estimate the four panel correction models (PECM). In this study, we have considered a maximum lag of one, which gave the following specification of the PECM:

$\Delta \mathrm{CFR}_{\mathrm{i}, \mathrm{t}}=\alpha_{\mathrm{i}}+\delta_{\mathrm{i}} \Delta \mathrm{RBAD}_{\mathrm{i}, \mathrm{t}}+\lambda_{\mathrm{i}}\left(\Delta \mathrm{CFR}_{\mathrm{i}, \mathrm{t}-1}-\widehat{\beta}_{\mathrm{i}} \Delta \mathrm{RBAD}_{\mathrm{i}, \mathrm{t}-1}\right)+\varepsilon_{\mathrm{i}, \mathrm{t}}$

with,

- $\mathrm{CFR}_{\mathrm{i}, \mathrm{t}}$ : Ratio based on cash flows (i.e., operating cash flows to total assets ratio) of company i for year $t$.

- $\mathrm{RBAD}_{\mathrm{i}, \mathrm{t}}$ : ratio based on accounting data (i.e., LIQR, EFFR, PROR, and SOLR) of company $i$ for year $t$.

- $\mathrm{CFR}_{\mathrm{i}, \mathrm{t}-1}$ : Ratio based on cash flows (i.e., operating cash flows to total assets ratio) of company i for year $\mathrm{t}-1$.

- $\mathrm{RBAD}_{\mathrm{i}, \mathrm{t}-1}$ : ratio based on accounting data (i.e., LIQR, EFFR, PROR, and SOLR) of company i for year $\mathrm{t}-1$.

- $\lambda_{\mathrm{i}}$ : the speed of adjustment coefficient or the error-correction coefficient.

- $\alpha_{i}$ and $\delta_{i}$ are the constant and the short-run relationship coefficient, respectively. 
- $\varepsilon_{\mathrm{i}, \mathrm{t}}:$ white noise.

- $\mathrm{i}=1,2 \ldots, \mathrm{N}$ denotes companies and $\mathrm{t}=1,2 \ldots, \mathrm{T}$ denotes year.

In this specification of the PECM, the short-run relationship is explained by $\beta$ and the long-run relationship is explained by $\lambda$ which is the error-correction coefficient. We recall that the estimation of each PECM allows to capture the possibility that the short-run relationship between the ratio based on cash flows (i.e., CFR) and one of the four ratios based on accounting data (i.e., LIQR, EFFR, PROR, and SOLR) reflects a fundamentally different phenomenon from that which characterizes the long-run equilibrium relationship between these two ratios. Statistically, this possibility is tested by identifying a coefficient $\lambda$ which is significantly different from zero. In addition, the estimation of each PECM allows to ensure that there is a long-run equilibrium relationship (i.e., cointegration relationship) between the ratio based on cash flows (i.e., CFR) and one of the four ratios based on accounting data (i.e., LIQR, EFFR, PROR, and SOLR). For this, we should identify a coefficient $\lambda$ which is negative and significantly different from zero. Indeed, if the coefficient $\lambda$ is not negative and significantly different from zero, then we can conclude that the PECM estimation should be rejected and so there is no cointegration since in such a case the error correction mechanism would go in the opposite direction and move away from the long-run equilibrium target.

In this study, we have used the approach of Pesaran, Shin and Smith (1999) to estimate our four panel error-correction models (PECM). In the literature on PECM, there are three estimation techniques, namely, the DFE (i.e., Dynamic Fixed-effects estimator), the PMG (i.e., Pooled Mean Group estimator), and MG (i.e., Mean Group estimator). We only present the results of the dynamic fixed-effects estimator (DFE) since the other two estimation techniques (i.e., PMG and MG) habitually lead to same findings regarding the sign and the significance of the error-correction coefficient $\lambda$.

Table 6 presents the results of the PECM estimation by the DFE technique for the following models:

PECM 1: $\Delta \mathrm{CFR}_{\mathrm{i}, \mathrm{t}}=\alpha_{\mathrm{i}}+\delta_{\mathrm{i}} \Delta \mathrm{LIQR}_{\mathrm{i}, \mathrm{t}}+\lambda_{\mathrm{i}}\left(\Delta \mathrm{CFR}_{\mathrm{i}, \mathrm{t}-1}-\widehat{\beta}_{\mathrm{i}} \Delta \mathrm{LIQR}_{\mathrm{i}, \mathrm{t}-1}\right)+\varepsilon_{\mathrm{i}, \mathrm{t}}$

PECM 2: $\Delta \mathrm{CFR}_{\mathrm{i}, \mathrm{t}}=\alpha_{\mathrm{i}}+\delta_{\mathrm{i}} \Delta \mathrm{EFFR}_{\mathrm{i}, \mathrm{t}}+\lambda_{\mathrm{i}}\left(\Delta \mathrm{CFR}_{\mathrm{i}, \mathrm{t}-1}-\widehat{\beta}_{\mathrm{i}} \Delta \mathrm{EFFR}_{\mathrm{i}, \mathrm{t}-1}\right)+\varepsilon_{\mathrm{i}, \mathrm{t}}$

PECM 3: $\Delta \mathrm{CFR}_{\mathrm{i}, \mathrm{t}}=\alpha_{\mathrm{i}}+\delta_{\mathrm{i}} \Delta \mathrm{PROR}_{\mathrm{i}, \mathrm{t}}+\lambda_{\mathrm{i}}\left(\Delta \mathrm{CFR}_{\mathrm{i}, \mathrm{t}-1}-\widehat{\beta}_{\mathrm{i}} \Delta \mathrm{PROR}_{\mathrm{i}, \mathrm{t}-1}\right)+\varepsilon_{\mathrm{i}, \mathrm{t}}$

PECM 4: $\Delta \mathrm{CFR}_{\mathrm{i}, \mathrm{t}}=\alpha_{\mathrm{i}}+\delta_{\mathrm{i}} \Delta \mathrm{SOLR}_{\mathrm{i}, \mathrm{t}}+\lambda_{\mathrm{i}}\left(\Delta \mathrm{CFR}_{\mathrm{i}, \mathrm{t}-1}-\widehat{\beta}_{\mathrm{i}} \Delta \mathrm{SOLR}_{\mathrm{i}, \mathrm{t}-1}\right)+\varepsilon_{\mathrm{i}, \mathrm{t}}$ 
Table 6: PECM estimation by DFE technique

\begin{tabular}{|c|c|c|c|c|}
\hline PECM & $\boldsymbol{\alpha}$ & $\boldsymbol{\delta}$ & $\boldsymbol{\lambda}$ & $\boldsymbol{F}$-test \\
\hline PECM 1 & $1.774 * * *$ & $1.481 * *$ & $-0.558 * *$ & 4.844 \\
& $(0.000)$ & $(0.032)$ & $(0.026)$ & $(0.000)$ \\
\hline PECM 2 & $0.976 * *$ & $1.228 * *$ & $-0.439 * *$ & 4.007 \\
& $(0.015)$ & $(0.041)$ & $(0.039)$ & $(0.000)$ \\
\hline PECM 3 & $2.796 * * *$ & $3.294 * * *$ & $-0.911 * * *$ & 5.752 \\
& $(0.000)$ & $(0.000)$ & $(0.000)$ & $(0.000)$ \\
\hline PECM 4 & $2.349 * * *$ & $2.715 * * *$ & $-0.978 * * *$ & 4.913 \\
& $(0.000)$ & $(0.002)$ & $(0.000)$ & $(0.000)$ \\
\hline
\end{tabular}

$(* * *),(* *),(*)$ statistically significant at $1 \%, 5 \%$, and $10 \%$, respectively. Numbers in parentheses represent p-value. $\mathrm{N}=150$ and $\mathrm{T}=8$.

These results indicate that the error-correction coefficients $\lambda$ for the four estimated PECM are significantly different from zero at $1 \%$ significance level for the models (CFR-PROR) and (CFR-SOLR) and at 5\% significance level for the models (CFRLIQR) and (CFR-EFFR). Thus, these results show that the short-run relationship of the ratio based on cash flows (i.e., CFR) with each ratio based on accounting data (i.e., LIQR, EFFR, PROR, and SOLR) differs from their long-run equilibrium relationship. In addition, the results of table 6 show that the coefficients $\lambda$ for the four estimated PECM are all statistically and significantly negative. Overall, these results confirm the existence of cointegration relationships for our four tested models, as we already have found by the panel cointegration tests of Pedroni (2004) in the previous section.

\section{Conclusion}

This study is an extension of the financial literature devoted to a heated debate on the uselessness of cash flows as an indicator of the company's financial health. Overall, the literature review shows that the various studies on this topic have generated highly contrasting results. In the present paper, we have used current developments in dynamic panel data econometrics techniques to alleviate methodological and econometric shortcomings noted in previous studies. To the best of our knowledge, this study constitutes the first research work that proposed to re-examine the relevance of cash flows as an indicator of the company's financial health via the cointegration tests on panel data. More precisely, we have tested the existence of a long-run equilibrium relationships (i.e., cointegration relationships) between a ratio based on cash flows (i.e., operating cash flows to total assets ratio) and four ratios based on accounting data which are commonly known as relevant indicators regarding the company's financial health through the following particular aspects: liquidity (i.e., working capital to total assets ratio), operational efficiency (i.e., asset turnover ratio), profitability (i.e., return on assets ratio), and solvency (i.e., debt-assets ratio). Thus, we have tested four research hypotheses which state that cash flows have explanatory power regarding one of these four aspects of a 
company's financial health mentioned above. In our empirical methodology, we have first used the test of Im, Pesaran and Shin (2003) to test the stationarity on our panel data. Subsequently, we have opted for the test of Pedroni (2004) in order to test the existence of a cointegration relationship between the ratio based on cash flows (CFR) and one of the four ratios based on accounting data (LIQR, EFFR, PROR, and SOLR). We have applied these two panel tests on a sample of 150 companies over a period of 8 years (i.e., 2010 to 2017), which gave us 1200 observations in panel data (company-year). We have ensured a certain level of homogeneity in our sample by considering two factors, namely, the size and the life cycle of the company.

The results of the tests of Im, Pesaran and Shin (2003) have showed that our five variables (CFR, LIQR, EFFR, PROR, and SOLR) are integrated of order 1 at a significance level of $1 \%$. These results have allowed us to apply the panel cointegration tests of Pedroni (2004) on the four models, namely (CFR-LIQR), (CFR-EFFR), (CFR-PROR), and (CFR-SOLR). The results of the tests of Pedroni (2004) have indicated the existence of cointegration relationships between CFR and the four ratios that measure the company's financial health (i.e., LIQR, EFFR, PROR, and SOLR). Overall, the results of the tests of Pedroni (2004) have permitted us to accept the four research hypotheses thus confirming the usefulness of the informational content of cash flows to explain and predict the company's financial health in terms of the following aspects: liquidity, operational efficiency, profitability, and solvency. However, we have found that the seven statistics of the test of Pedroni (2004) (i.e., three statistics of the between-dimension category and four statistics of the within-dimension category) have not given the same results concerning the rejection of the null hypothesis of no cointegration. Thus, we have used the number of statistics ((with priority to the number of statistics of the between-dimension category) that reject the null hypothesis as well as their significance level to compare the powerfulness of the cointegration relationships identified between the ratio based on cash flow (CFR) and the four ratios based on accounting data (LIQR, EFFR, PROR, and SOLR).

The results of this comparison have allowed us to establish the following ranking: 1st rank: The model (CFR -SOLR), which displays the most powerful cointegration relationship.

2nd rank: The model (CFR -PROR).

3rd rank: The model (CFR - EFFR).

4th rank: The model (CFR - LIQR), which displays the weakest cointegration relationship among the four tested models.

Given that the debt-assets ratio (SOLR) is also called long-term solvency ratio, so we have concluded from this ranking that the explanatory power of cash flows with regard to the solvency of the company is more powerful than that with regard to its profitability, its operational efficiency, or its liquidity. This finding is consistent with studies that have confirmed the usefulness of cash flows in business failure prediction. Indeed, bankruptcy is supposed to occur when the company has a serious solvency problem. Specifically, when the value of the company becomes too low 
for a funder (common shareholders, creditors, and preferred shareholders) to agree to continue funding it in the event of default. It is in such a context that cash flows become very useful in predicting the company bankruptcy, since according to the fundamental analysis the value of the company is equal to the discounted sum of future cash flows generated by all of its current investment projects. We recall also that the other aspects of company's financial health namely its liquidity, its management efficiency, and its profitability are all important determinants in the business failure prediction. The results of our study reinforce the idea on the usefulness of cash flows to predict the company bankruptcy since we have detected cointegration relationships between CFR and the three other ratios which measure the company's financial which are LIQR (i.e., liquidity), EFFR (i.e., operational efficiency), and PROR (i.e., profitability).

In order to analyze the robustness of our results, we have used the approach of Pesaran, Shin and Smith (1999) to estimate panel error correction models (PECM) by the dynamic fixed-effects (DFE) technique. The results have indicated, that the error-correction coefficients $\lambda$ for the four estimated PECM are statistically and significantly negative and different from zero, thus confirming the results of the panel cointegration tests of Pedroni (2004). In other words, the PECM estimations are supportive of the existence of a long-run equilibrium relationships between the ratio based on cash flow (CFR) and the four ratios based on accounting data, namely: LIQR, EFFE, PROR, and SOLR.

In short, these are the main results of this study. Of course, the results would be more robust if we had been able to remedy the problem of inter-individual dependence raised by Moon and Perron (2004). The most widely used technique to alleviate the effects of such a problem is the demeaning data approach, which consists in the adjustment of the data by subtracting the sample mean of each observation. However, the demeaned approach is not very appropriate for financial data since it tends to stationary the series at the level, which no longer allows the application of cointegration tests on panel data.

As a future avenue of research, we suggest re-examining the empirical validation of the present study by the use of the second-generation dynamic panel tests, which admit the hypothesis of interindividual dependencies, particularly, the panel stationarity test of Choi (2006) and the panel cointegration test of Banerjee and Carrion-i-Silvestre (2006 and 2011). 


\section{References}

[1] Altman, E.I. (1968). Financial Ratios, Discriminant analysis, and the prediction of corporate bankruptcy. The Journal of Finance, vol. 23, no. 4, pp. $589-609$.

[2] Arthur, N., Czernkowski, R. and Chen, M. (2007). The persistence of cash flow components into future earnings. Working Paper, University of Sydney.

[3] Banerjee, A. and Carrion-i-Silvestre J.L. (2006). Cointegration in panel data with breaks and cross-section dependence. Working Paper Series, no.591, European Central Bank.

[4] Banerjee, A. and Carrion-i-Silvestre, J.L. (2011). Testing for panel cointegration using common correlated effects estimators. Working Paper, University of Barcelona.

[5] Beaver, W.H. (1966). Financial ratios as predictors of failure. Journal of Accounting Research (Supplement), pp.71 - 111.

[6] Blum, M. (1974). Failing company discriminant analysis. Journal of Accounting Research, Spring, pp.1 - 25.

[7] Bowen, R. M., Burgstahler D. and Daley L.A. (1986). Evidence on the relationships between earnings and various measures of cash flow. The Accounting Review, vol. 61, no. 4, pp.713 - 725.

[8] Burgstahler, D., Jiambalvo J. and Pyo Y. (1998). The informativeness of cash flows for future cash flows. Working paper, University of Washington.

[9] Bushman, R. M., Lerman A. and X. F. Zhang, X.F. (2016). The changing landscape of accrual accounting. Journal of Accounting Research, vol. 54, no. 1, pp. 41-78.

[10] Brooks, J. E. (1981). An Empirical investigation of the usefulness of earnings in predicting future enterprise cash flows. Working Paper, Michigan State University.

[11] Casey, C.J. and Bartczak, N.J. (1984). Cash Flow - It's Not The Bottom Line', Harvard Business Review, pp.61 - 66.

[12] Chen, C. W., Melessa, S. and Mergenthaler, R. (2017). Revisiting measurement error in surrogate measures of operating cash flows: Have we solved the problem? Working paper

[13] Choi, I. (2006). Combination unit root tests for cross-sectionally correlated panels. in D. Corbae, S.N. Durlauf\& B.E. Hansen (eds), Econometric Theory and Practice: Frontiers of Analysis and Applied Research, Cambridge University Press, pp. 311- 333.

[14] Chotkunakitti, P. (2005). Cash flows and accrual accounting in predicting future cash flow of Thai listed companies. DBA thesis, Southern Cross University Lismore, NSW.

[15] Deakin, E.B. (1972). A discriminant analysis of predictors of business failure', Journal of Accounting Research, pp.167-179. 
[16] Dechow, P. M. (1994). Accounting earnings and cash flows as measures of firm performance: The role of accounting accruals. Journal of Accounting and Economics, vol. 18, no. 1, pp. 3 - 42.

[17] Dechow, P. M., Kothari, S.P. and Watts, R.L. (1998). The relation between earnings and cash flows. Journal of Accounting and Economics, vol. 25, no. 2, pp.133-168.

[18] Ebaid, I. E. (2011). Accruals and the prediction of future cash flows: empirical evidence from an emerging market. Management Research Review, vol. 34, no. 7, pp. 1-32.

[19] Finger, C. A. (1994). The ability of earnings to predict future earnings and cash flow. Journal of Accounting Research, vol. 32, no. 2, pp. 210-223.

[20] Greenberg, R.R., Johnson, G.L. and Ramesh, K. (1986). Earnings versus cash flow as a predictor of future cash flow measures. Journal of Accounting, Auditing \& Finance, vol. 1, no. 4, pp.266-277.

[21] Holmen, J. (1988). Using financial ratios to predict bankruptcy: an evaluation of classic models using recent evidence. Akron Business and Economic Review, vol. 19, no. 1, pp. 52-63.

[22] Im K.S., Pesaran M.H. and Shin, Y. (2003). Testing for unit roots in heterogeneous panels. Journal of Econometrics, vol.115, pp. 53-74. [4] Blum, M. (1974). Failing company discriminant analysis. Journal of Accounting Research, Spring, pp. 1 - 25.

[23] Kim, M. and Kross. W. (2005). The ability of earnings to predict future operating cash flows has been increasing-not decreasing. Journal of Accounting Research, vol. 43, no. 5, pp. 753-780.

[24] Lorek, K.S. and Willinger, G.L. (1996). A multivariate time-series prediction model for cash-flow data. The Accounting Review, vol. 71, no. 1, pp. 81-102.

[25] Lorek, K.S. and Willinger, G.L. (2009). New evidence pertaining to the prediction of operating cash flows. Review of Quantitative Finance and Accounting, vol. 32, no. 1, pp. 1-15.

[26] Moon, H.R. and Perron, B. (2004). Testing for a unit root in panels with dynamic factors. Journal of Econometrics, vol. 122, pp. 81-126.

[27] Murdoch, B. and Krause, P. (1989). An empirical investigation of the predictive power of accrual and cash flow data in forecasting operating cash flow. Akron Business and Economic Review, vol. 20, no. 3, pp. 100-113.

[28] Nam, S., Brochet, F. and Ronen, J. (2012). The predictive value of accruals and consequences for market anomalies. Journal of Accounting, Auditing \& Finance, vol. 27, no. 2, pp.151-176.

[29] Pae J. (2005). Expected accrual models: the impact of operating cash flows and reversals of accruals. Review of Quantitative Finance and Accounting, vol. 24, no. 1, pp. 5-22.

[30] Pedroni, P. (1997). On the role of cross-sectional dependency in panel unit root and panel cointegration exchange rate studies. Working Paper, Indiana University. 
[31] Pedroni, P. (2000). Fully-modified OLS for heterogeneous cointegration panel. Advances in Econometrics, vol. 15, pp. 93-130.

[32] Pedroni, P. (2004): Panel Cointegration. Asymptotic and Finite Sample Properties of Pooled Time Series Tests with an Application to the PPP Hypothesis, Econometric Theory, 20, 3, 597-625.

[33] Penham, S.H. and Yehuda, N. (2009). The pricing of earnings and cash flows and the affirmation of accrual accounting. Review of Accounting Studies, vol. 14, no. 4, pp. 453-479.

[34] Pesaran, M.H., Shin Y. and Smith, R.P. (1999). Pooled mean group estimation of dynamic heterogeneous panels. Journal of the American Statistical Association, vol. 94, pp. 621-634.

[35] Saint-Pierre, J. (1985). Le contenu informatif des flux monétaires. CA Magazine, August, pp. 66-70.

[36] Seng, D. (2006). Earnings versus cash flows as predictors of future cash flows: New Zealand evidence. Working Paper, University of Otago.

[37] Subramanyam, K.R. and Venkatachalam, M. (2007). Earnings, cash flows, and ex post intrinsic value of equity. The Accounting Review, vol. 82, no. 2, pp. 457- 481.

[38] Waldron, M.A. and Jordan, C.E. (2010). The comparative predictive abilities of accrual earnings and cash flows in periods of economic turbulence: the case of the bubble. The Journal of Applied Business Research, vol. 26, no. 1, pp. 85-97. 